\title{
Willingness To Pay (WTP) jasa lingkungan sumberdaya air tanah sumur di Kota Kupang
}

\author{
Willingness To Pay (WTP) for environmental services of well water sources in Kupang City \\ Aplonia Bani ${ }^{\mathrm{a}}$, Fredrik Benu ${ }^{\mathrm{a}}$, Herry Kotta ${ }^{\mathrm{a}}$ \\ ${ }^{\text {a }}$ Program Studi Ilmu Lingkungan, Pascasarjana, Universitas Nusa Cendana Kupang, Indonesia
}

Article Info:

Received: 14 - 10 - 2019

Accepted: 08 - 04 - 2020

Keywords:

Commercial well, groundwater

basin, payments for

environmental services,

Willingness To Pay

Corresponding Author:

Aplonia Bani

Program Studi lmu Lingkungan,

Pascasarjana, Universitas Nusa

Cendana Kupang;

Tel. +6281339000535

Email:

aplonia_bani@yahoo.com

\begin{abstract}
Research in Kupang City, East Nusa Tenggara Province was conducted in August 2018, and aimed to know the level of groundwater utilization in the region. Primary data collection was carried out through surveys with interviews to residents of Kupang City as the owner of the well who sold 20 people water. Data analysis was performed using a Willingness To Pay approach. The results showed that the value of the Willingness To Pay well owners who are willing to pay as many as 17 respondents is Rp 518209 or Rp 6100 per cubic meter. This WTP value is still relatively low because both producers and consumers still pay less than they should. However, efforts to increase water prices need to pay attention to factors that influence consumers' Willingness To Pay. While Revenue $\left(x^{4}\right)$ and Service $\left(x^{6}\right)$ have strong risk factors meaning that these factors pose a strong risk to the respondents' Willingness To Pay (WTP), so that a partially significant effect is between the acceptance and knowledge of environmental services on the availability the owner of the well in paying groundwater environmental services used as economic goods. The acceptance and knowledge of environmental services have a significant effect because the greater the acceptance and knowledge of environmental services, the higher the Willingness To Pay for environmental services.
\end{abstract}

How to cite (CSE Style $8^{\text {th }}$ Edition):

Bani A, Benu F, Kotta H. 2020. Willingnes To Pay (WTP) jasa lingkungan sumberdaya air tanah sumur di Kota Kupang. JPSL 10(2): 173-182. http://dx.doi.org/10.29244/jps1.10.2.173-182.

\section{PENDAHULUAN}

Saat ini warga Kota Kupang di Provinsi Nusa Tenggara Timur banyak yang membuat sumur lalu memperjualbelikan airnya dengan harga antara Rp 80000 hingga Rp 200000 setiap satu truk tangki bervolume 5000 liter tergantung musim dan jarak angkut dari depo pengisian ke rumah pelanggan (Salean, 2017). Pengambilan air tanah yang berlebihan dikhawatirkan dapat mengganggu ekosistem dan kelestarian alam apabila tidak dijaga keseimbangan jasa lingkungan, karena jika pengambilan air tanah secara berlebihan melebihi jumlah pengisian akuifer berpotensi mengeringnya mata air permukaan dan menurunnya muka air tanah serta terjadinya intrusi air laut. Dibutuhkan manajemen pemanfaatan air tanah secara optimal dan pemanfaatan daerah tangkap air yang memadai untuk menjaga keberlangsungan dan ketersediaan sumber air bawah tanah, sebagaimana yang telah diamanahkan dalam Peraturan Menteri Energi dan Sumberdaya Mineral Republik Indonesia Nomor 2 Tahun 2017 Pasal 2 ayat (1), yaitu: "Air tanah adalah air yang terdapat di dalam 
lapisan tanah atau batuan di bawah permukaan tanah. Sumberdaya air termasuk didalamnya air tanah dikelola secara menyeluruh, terpadu, dan berwawasan lingkungan hidup dengan tujuan untuk mewujudkan kemanfaatan air yang berkelanjutan untuk sebesar-besarnya kemakmuran rakyat. Air tanah dikelola dengan prinsip keterpaduan dengan air permukaan".

Dalam hal ini, pemerintah mempunyai peran besar dalam pengelolaan sumber daya alam yang menjadi hajat hidup orang banyak sebagaimana yang telah diamanahkan oleh Pasal 33 ayat 3 UUD 1945, bahwa:

"Bumi, air dan kekayaan alam yang terkandung didalamnya dikuasai oleh negara dan dipergunakan untuk sebesar-besarnya kemakmuran rakyat". Organisasi Kesehatan Dunia (WHO) juga telah menerbitkan buku berjudul The Right To Water yang menempatkan tugas pemerintah setiap negara untuk hak atas air. Ada tiga tugas utama pemerintah setiap negara mengenai hak atas air yakni duty to respect, duty to protect, dan duty to fulfill agar pemanfaatan air tanah tidak sampai mengganggu persediaan air tanah, atau tidak merusak kualitas air yang sudah disediakan oleh alam (Sultana dan Loftus, 2013).

Peraturan mengenai pemanfaatan air tanah di Kota Kupang tersebut perlu disusun berdasarkan pendekatan Willingness To Pay, yaitu tingkat kesediaan masyarakat untuk mengeluarkan imbalan atas sumberdaya air yang diperolehnya. Semakin langka air maka orang akan semakin terpancing untuk berpikir dan memandang air sebagai barang ekonomi (economic goods) seperti yang tercantum dalam pernyataan Dublin Principles (1992) dalam Rahaman dan Varis (2005): "Water has an economic value in all its competing uses and should be recognized as an economic goods". Penelitian ini dilakukan dengan tujuan mendapatkan tingkat kesediaan masyarakat untuk membayar air tanah yang dibutuhkan untuk menjamin pemanfaatan air tanah yang berwawasan lingkungan dan pelestariannya.

\section{METODE PENELITIAN}

\section{Lokasi dan Waktu Penelitian}

Penelitian ini dilakukan mulai dari bulan Maret sampai dengan bulan Agustus 2018. Lokasi penelitian pada daerah cekungan air tanah Kota Kupang yang terdapat sumur yang dimanfaatkan sebagai barang ekonomi yang di jual ke konsumen yaitu pada CAT Bolok - Tenau - Alak - Namosain, CAT Tabun - Bakunase Haukoto - Sikumana, CAT Kupang - Oesapa - Tarus, CAT Penfui dan CAT Baumata.

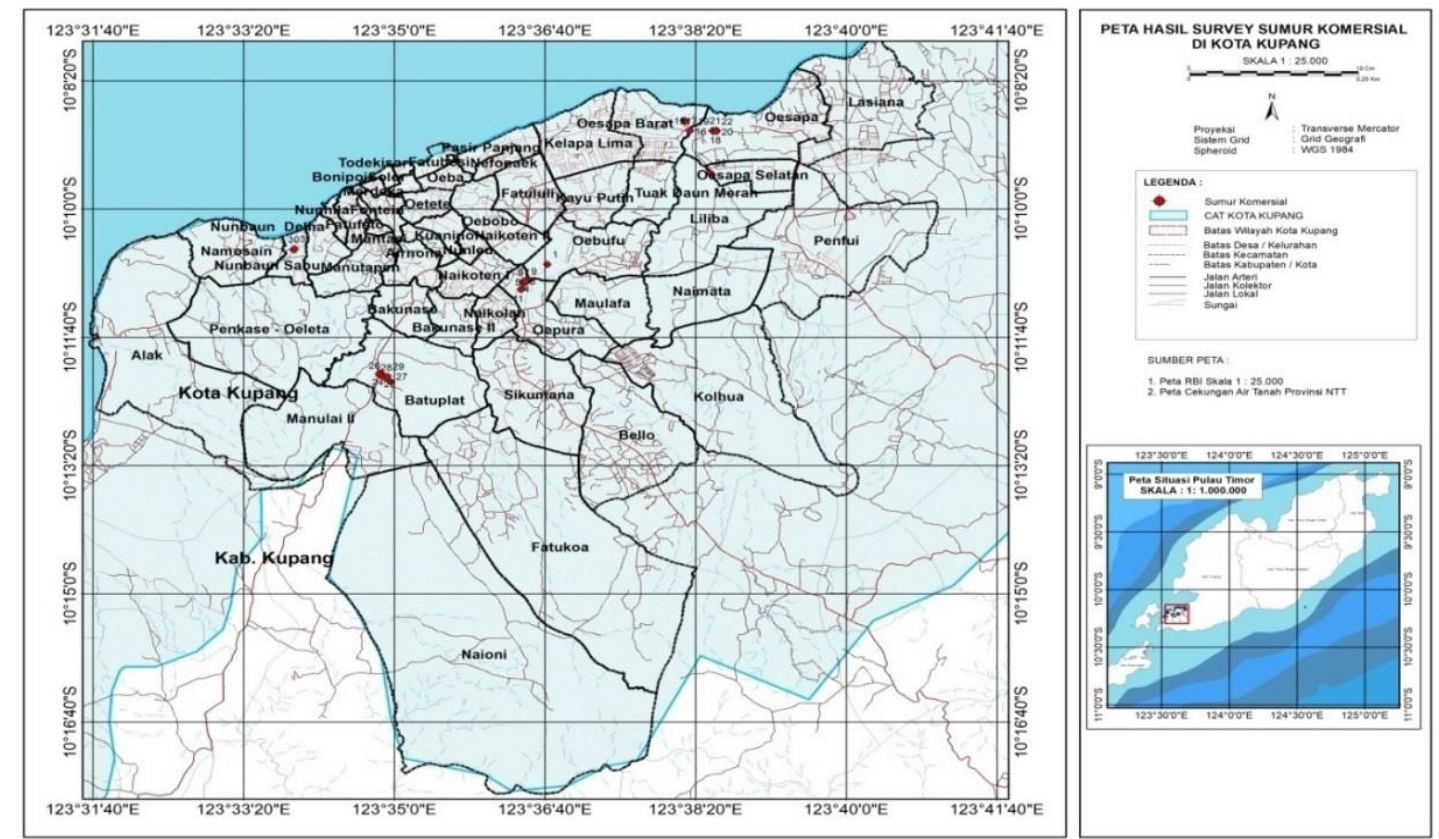

Gambar 1 Peta cekungan air tanah di Kota Kupang 


\section{Metode Pengumpulan Data}

Upaya untuk memperoleh data yang dibutuhkan dalam penelitian ini yaitu dengan menggunakan teknik pengumpulan data melalui metode pengumpulan data yang dilakukan sebagai berikut:

a. Data primer melalui teknik survei dan wawancara (interview) kepada responden berdasarkan kuesioner yang dipersiapkan. Survei lapangan untuk mengetahui kondisi riil pemanfaatan sumur yang dijadikan economic goods di daerah studi.

b. Data sekunder diambil dari instansi terkait yang berhubungan dengan masalah penulisan. Data yang digunakan adalah hasil survei sumur yang dijadikan economic goods di Kota Kupang, data izin operasional, peta sebaran sumur dan data lainnya yang relevan.

\section{Metode Analisis Data}

\section{Analisis Tingkat Penerimaan Responden Terhadap Pembayaran Jasa Lingkungan}

Analisis ini dilakukan dengan menggunakan metode analisis regresi logit dikarenakan penentuan tingkat penerimaan responden terhadap pembayaran jasa lingkungan dikumpulkan melalui data binner, yaitu bentuk data yang menggambarkan pilihan "ya atau tidak". Hal yang membedakan model regresi logit dengan regresi biasa adalah peubah terikat dalam model bersifat dikotomi atau data dari hasil perhitungan berupa data diskrit, data kategorik atau data nominal sehingga tidak dijumpai bilangan pecahan (Hosmer dan Lameshow, 1989). Bentuk fungsi ini model logit adalah:

$$
\log \mathrm{y}=\beta_{0}+\beta_{1} \log \mathrm{X}_{1}+\beta_{2} \log \mathrm{X}_{2}+\beta_{3} \log \mathrm{X}_{3}+\beta_{4} \log \mathrm{X}_{4}+\beta_{5} \log \mathrm{X}_{5}+\beta_{6} \log \mathrm{X}_{6} \varepsilon
$$

$\log \mathrm{y}=\beta_{0}+\beta_{l}$ tingkat pendidikan $+\beta_{2}$ pekerjaan $_{i}+\beta_{3}$ pendapatan $_{i}+\beta_{4}$ biaya operasional $_{i}+\beta_{5}$ pengetahuan $_{i}+\varepsilon_{i}$

Keterangan:

$\begin{array}{ll}\log \mathrm{y} & \begin{array}{l}\text { Peluang responden setuju atau tidak dengan imbal jasa lingkungan (bernilai } 1 \\ \text { untuk "setuju" dan bernilai } 0 \text { untuk "tidak setuju") }\end{array} \\ = & \text { Intersep nilai rata-rata variabel y (WTP) } \\ \beta_{0} & \text { Koefisien dari regresi: Umur, tingkat Pendidikan, pekerjaan, pendapatan, } \\ \beta_{1}, \beta_{2}, \beta_{3}, \beta_{4}, \beta_{5}, \beta_{6}= & \text { biaya operasional, pengetahuan jasa lingkungan } \\ \varepsilon & \text { Galat } 0.05\end{array}$

Tabel 1 Pengkategorian variabel bebas penelitian

\begin{tabular}{clc}
\hline Variabel & \multicolumn{1}{c}{ Nama Variabel } & Kategori \\
\hline $\mathrm{y}$ & $\begin{array}{l}\text { Willingness To Pay masyarakat pemilik sumur } \\
\text { bor yang dijual di Kota Kupang }\end{array}$ & $0=$ Tidak \\
$x_{1}$ & Umur & $1=$ Ya \\
$x_{2}$ & Tingkat Pendidikan & (Tahun) \\
& & Tidak Sekolah $=0$ \\
& & SD $=1$ \\
& & SMP $=2$ \\
$x_{3}$ & Pekerjaan & SMA $=3$ \\
& & Perguruan Tinggi $=4$ \\
$x_{4}$ & Penerimaan & $0=$ Sampingan \\
$x_{5}$ & Biaya operasional & $1=$ Tetap \\
$x_{6}$ & Pengetahuan Jasa Lingkungan & Rp/Bulan \\
& & Rp/Bulan \\
& & $0=$ tidak tau \\
\end{tabular}

Sumber: Hasil analisis 2018 


\section{Kesediaan Membayar Willingness To Pay Jasa Lingkungan}

Menurut Dixon dan Hufschmidt (1993), pendekatan Willingness To Pay adalah pendekatan dengan teknik survey untuk mengetahui kesediaan untuk membayar (Willingness To Pay) dari konsumsi suatu barang lingkungan dalam hal ini adalah sumberdaya air sumur yang dijual oleh masyarakat Kota Kupang. Jangkauan kesediaan membayar (Willingness To Pay) akan dikelompokkan ke dalam kelas, dengan menggunakan pendekatan Sturges (Dajan, 1976) sebagai berikut:

Keterangan:

$$
\mathrm{K}=1+3.3 \log \mathrm{n}
$$

$\mathrm{K}=$ jumlah kelas;

$\mathrm{n}=$ jumlah angka yang terdapat dalam data (sampel)

Setelah dihitung maka jumlah kelas $(k)=5.97$ dibulatkan menjadi 6 kelas karena merupakan data diskrit atau tidak berbentuk pecahan. Sedangkan untuk mengetahui besarnya interval dalam kelas dapat diperkirakan sebagai berikut:

$$
i=\frac{j a r a k}{1+3.3 \log n}
$$

Keterangan:

$\mathrm{i} \quad=$ interval kelas

Jarak $=$ kesediaan membayar tertinggi - kesediaan membayar terendah

Setelah dihitung maka interval kelas (i) dan jangkauan kesediaan membayar dapat dikelompokkan kedalam kelas dengan interval kelas maka kesediaan untuk membayar (Willingness To Pay) oleh pemilik sumur yang dijual akan dihitung dengan rumus sebagai berikut, Dixon dan Hufschmidt (1993):

$$
T W P=\sum_{i=1}^{n} A W P_{i}\left(\frac{n_{i}}{N}\right) \times \text { Populasi }
$$

Keterangan:

TWP $=$ Total Willingness To Pay

$\mathrm{AWP}_{\mathrm{i}}=$ Kesediaan membayar responden, jumlah 1 sampai dengan 7

ni $\quad=$ Banyaknya responden yang bersedia membayar sebesar $\mathrm{AWP}_{\mathrm{i}}$

$\mathrm{N} \quad$ = Banyaknya orang yang diwawancarai sebagai sampel

$\mathrm{P} \quad=$ Populasi

\section{Pengujian Model Kesediaan Membayar Jasa Lingkungan}

Model analisis yang digunakan adalah model analisis regresi linier berganda. Model ini digunakan untuk mengetahui pengaruh variabel bebas terhadap variabel terikat dengan persamaan sebagai berikut (Walpole, 2015).

$$
\hat{y}=b_{0}+b_{1} x_{1}+b_{2} x_{2}+b_{3} x_{3}+b_{4} x_{4}+b_{5} x_{5}+b_{6} x_{6}+\varepsilon
$$

Keterangan:

$b_{0}=$ Intersep (nilai rata-rata y)

$$
\begin{array}{ll}
x_{1} & =\text { Umur } \\
x_{3} & =\text { Pekerjaan } \\
x_{5} & =\text { Biaya operasional } \\
b_{1,2,3,4,5,6} & =\text { Koefisien regresi variabel } x_{1,2,3,4,5}
\end{array}
$$$$
x_{2}=\text { Tingkat Pendidikan }
$$$$
x_{4}=\text { Penerimaan }
$$$$
x_{6}=\text { Pengetahuan jasa lingkungan }
$$

$\varepsilon=$ Error 
Koefisien determinasi $\mathrm{R}^{2}$ digunakan untuk mengukur kedekatan hubungan antara variabel bebas yang digunakan dengan variabel terikat. Koefisien determinasi adalah angka yang menunjukkan besarnya proporsi atau persentase variasi variabel terikat yang dijelaskan oleh variabel bebas secara bersama-sama. Besarnya $\mathrm{R}^{2}$ berada diantara 0 dan $1\left(0<\mathrm{R}^{2}<1\right)$. Hal ini menunjukkan bahwa semakin mendekati satu, nilai $\mathrm{R}^{2}$ berarti dapat dikatakan bahwa model tersebut baik. Karena semakin besar hubungannya antara variabel bebas dengan variabel terikat. Dengan kata lain, semakin mendekati satu maka variasi variabel terikat hampir seluruhnya dipengaruhi dan dijelaskan oleh variabel bebas.

\section{HASIL DAN PEMBAHASAN}

\section{Gambaran Umum Sumur yang dikomersilkan di Kota Kupang}

Hasil pengamatan dilokasi penelitian terdapat 32 sumur komersil, dengan jumlah pemilik sebanyak 20 orang. Hal ini dikarenakan sebagian dari pemilik sumur komersil memiliki lebih dari satu sumur air komersil, dengan kedalaman rata-rata 6-15 meter dan debit air pada saat pengambilan 835 tangki/hari dengan kapasitas $5000 \mathrm{~L}$ atau sebanyak $4175 \mathrm{~m}^{3}$. Informasi mengenai kesediaan membayar (WTP) responden maka peneliti menyusun beberapa pertanyaan dalam kuesioner untuk mendapatkan informasi tentang kesediaan membayar (WTP) responden. Tujuan penelitian adalah untuk mengetahui kesediaan pemilik sumur membayar jasa lingkungan sumberdaya air tanah yang dijual dan besaran nilai WTP per bulan yang bersedia dibayarkan responden. Berdasarkan hasil wawancara didapat kesimpulan yang menjawab setuju membayar sebanyak $85 \%$ dan yang menjawab tidak setuju sebanyak $15 \%$.

Tabel 2 Kesediaan membayar (WTP) responden

\begin{tabular}{clccc}
\hline No & & WTP & Responden (orang) & Persentase (\%) \\
\hline 1 & Setuju & 17 & 85 \\
2 & Tidak Setuju & 3 & 15 \\
\hline & Jumlah & & 20 & 20 \\
\hline
\end{tabular}

${ }^{a}$ WTP: Willingness To Pay

\section{Analisis Tingkat Penerimaan Responden terhadap Pembayaran Jasa Lingkungan}

Analisis peluang responden setuju atau tidak setuju dengan penentuan tingkat penerimaan responden terhadap pembayaran jasa lingkungan yang dikumpukan melalui data binner yang menggambarkan pilihan ya atau tidak. Adapun dari tabel di atas dapat ditunjukkan bahwa model regresi logistik yang digunakan telah cukup baik, karena mampu menebak dengan benar 85\% kondisi yang terjadi. Dari 20 responden yang diwawancarai terdapat 17 yang menjawab setuju dan 3 yang menjawab tidak setuju.

\section{Partial Test / Uji Parsial}

Pengujian ini dilakukan untuk menguji apakah setiap variabel bebas mempunyai pengaruh yang signifikan terhadap variabel terikat. Variabel apa yang mempunyai pengaruh dalam penelitian ini.

Tabel 3 Variables in the equation

\begin{tabular}{cccccccc}
\hline & & B & S.E. & Wald & df & Sig. & Exp(B) \\
\hline Step 0 & Constant & 1.735 & .626 & 7.673 & 1 & .006 & 5.667 \\
\hline
\end{tabular}

${ }^{a} B$ : koefisien beta, df: degree of freedom, Wald: uji wald, Sig.: nilai signifikansi, $\operatorname{Exp}(B)$ : odds ratio 
Dalam penelitian ini sesuai dengan output di atas dapat ditunjukkan bahwa variabel pengetahuan jasa lingkungan signifikan mempengaruhi variabel WTP dengan tingkat signifikan 0.015. Hal ini sesuai dengan pernyataan pada pengujian simultan bahwa minimal ada satu variabel bebas yang signifikan dengan kriteria pengambilan keputusan: $\mathrm{H0}$ : $\mathrm{b} 1=0$ (tidak ada pengaruh signifikan dari pengetahuan jasa lingkungan terhadap WTP); H1: b1 $\neq 0$ (ada pengaruh signifikan dari pengetahuan jasa terhadap variabel WTP). Dalam penelitian ini dapat disimpulkan bahwa dengan tingkat keyakinan 95\% variabel jasa lingkungan signifikan mempengaruhi WTP dengan tingkat signifikan lebih kecil dari 0.05 .

\section{Mengestimasi Besarnya Nilai Total Willingness To Pay (WTP)}

Total WTP pada Tabel 4 dapat digunakan untuk menduga WTP populasi secara keseluruhan dengan rumus Dixon dan Hufschmidt (1993):

$$
T W P=\sum_{i=1}^{n} A W P_{i}\left(\frac{n_{i}}{N}\right) x \text { Populasi }
$$

Keterangan:

TWP $=$ Total Willingness To Pay

$\mathrm{AWP}_{\mathrm{i}}=$ Kesediaan membayar responden

ni $\quad=$ Banyaknya responden yang bersedia membayar sebesar AWPi

$\mathrm{N} \quad=$ Banyaknya orang yang diwawancarai sebagai sampel

$\mathrm{P} \quad=$ Populasi

Tabel 4 Besarnya nilai WTP

\begin{tabular}{ccccc}
\hline $\begin{array}{c}\text { Rata-rata AWP Per } \\
\text { Responden }\end{array}$ & Jumlah Responden & Total WTP Responden & $\begin{array}{c}\text { Jumlah } \\
\text { Populasi }\end{array}$ & $\begin{array}{c}\text { Total WTP } \\
\text { Populasi (Rp) }\end{array}$ \\
\hline 31000 & 17 & 527000 & 20 & 10540000 \\
\hline
\end{tabular}

${ }^{a}$ AWP: kesediaan membayar responden, TWP: total willingness to pay

Berdasarkan hasil perhitungan rata-rata WTP per responden Rp 31000 per $5 \mathrm{~m}^{3}$ atau sebesar Rp $6200 / \mathrm{m}^{3}$ dengan total WTP dari 17 responden yang bersedia membayar sebesar Rp 527000 dengan nilai WTP kesediaan membayar jasa lingkungan untuk sumur yang dikomersilkan dengan menggunakan mobil tangki sebesar Rp 10540000. Dari nilai kesediaan membayar responden kemudian dirata-ratakan, sehingga diperoleh nilai ratarata kesediaan membayar untuk setiap pengambilan air per CAT, di bagi kedalam 4 wilayah CAT yaitu pada daerah Oepura sebesar Rp 210000, Bakunase sebesar Rp 200000, Oesapa sebesar Rp 130000, Alak sebesar Rp 60000 dan Penfui sebesar Rp 20000 dengan rata-rata jumlah WTP di bagi n sebesar 20. Hasilnya dapat dilihat pada Tabel 5 di bawah ini :

Tabel 5 Nilai rata-rata kesediaan membayar responden per CAT pengambilan air

\begin{tabular}{clccccc}
\hline No & \multicolumn{1}{c}{ Uraian } & \multicolumn{5}{c}{ WTP/Pengambilan Air perCAT $\left(\mathrm{m}^{3}\right)$} \\
\hline 1 & Jummlah Total $/ \sum \mathrm{WTP}(\mathrm{Rp})$ & 210000 & 200000 & 130000 & 60000 & 20000 \\
2 & Rata-rata WTP $/\left(\sum \mathrm{WTP} / \mathrm{n}\right)$ & 10500 & 10000 & 6500 & 3000 & 1000 \\
3 & Rata-rata Kubikasi $\left(\mathrm{m}^{3}\right)$ & 7.5 & 15 & 56.25 & 61.25 & 68.75 \\
\hline
\end{tabular}

${ }^{\mathrm{a}} \mathrm{CAT}$ : cekungan air tanah, $\mathrm{m}^{3}$ : meter kubik, WTP: willingness to pay, $\mathrm{n}$ : sampel 
Kemudian dilakukan regresi sederhana, dari hasil regresi diintegralkan dan didapat nilai WTP responden dari 17 responden yang bersedia membayar. Hasil regresi sederhana dapat dilihat pada Gambar 2.

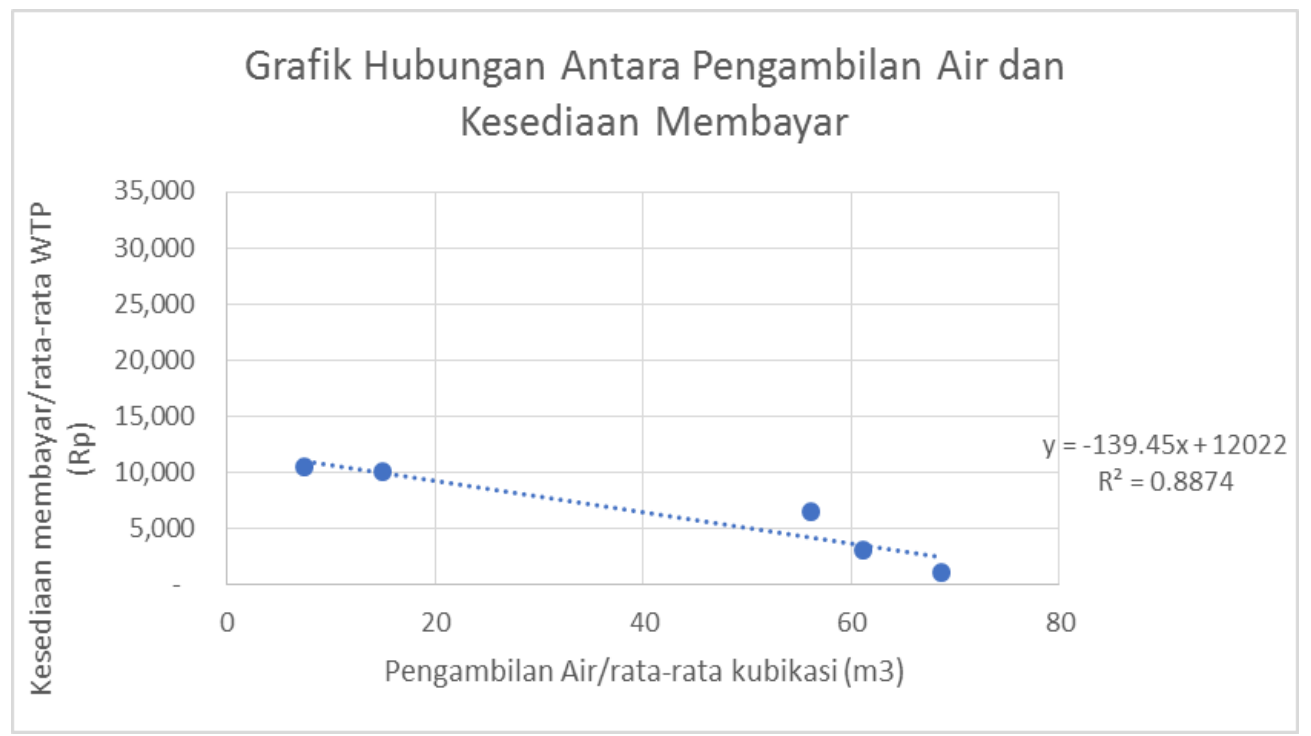

Gambar 2 Grafik hasil regresi sederhana

Dari hasil regresi sederhana diperoleh persamaan :

$$
\begin{aligned}
\mathrm{Y} & =12022-139.45 \mathrm{X} \\
\text { Jika X } & =0, \text { maka } \mathrm{Y}=12022 \\
\text { Jika Y } & =0, \text { maka: } \\
0 & =12022-139.45 \mathrm{X}_{1} \\
\mathrm{X}_{1} & =\underline{12022} \\
\mathrm{X}_{1} & =86.21
\end{aligned}
$$

Berdasarkan hasil perhitungan di atas dapat digambarkan dalam grafik pada Gambar 3, yang menjelaskan jika $\mathrm{X}=0$, maka $\mathrm{Y}=12022$ dan jika $\mathrm{Y}=0$, maka $\mathrm{X}=86.21$. Untuk mendapatkan nilai WTP maka fungsi ini harus diintegralkan $: \mathrm{Y}=\int_{0}^{86.21}(12022-139.45 X 1) d x ; \mathrm{Y}=\{12022 \mathrm{X}-1 / 2.86 .21 \mathrm{X} 1\}^{86.21} ; \mathrm{Y}=1 / 2.86 .21 .12022$; $\mathrm{Y}=518209.31$. Jadi nilai Total WTP (Willingness To Pay) dari 17 responden yang bersedia membayar WTP sebesar Rp 518209.31.

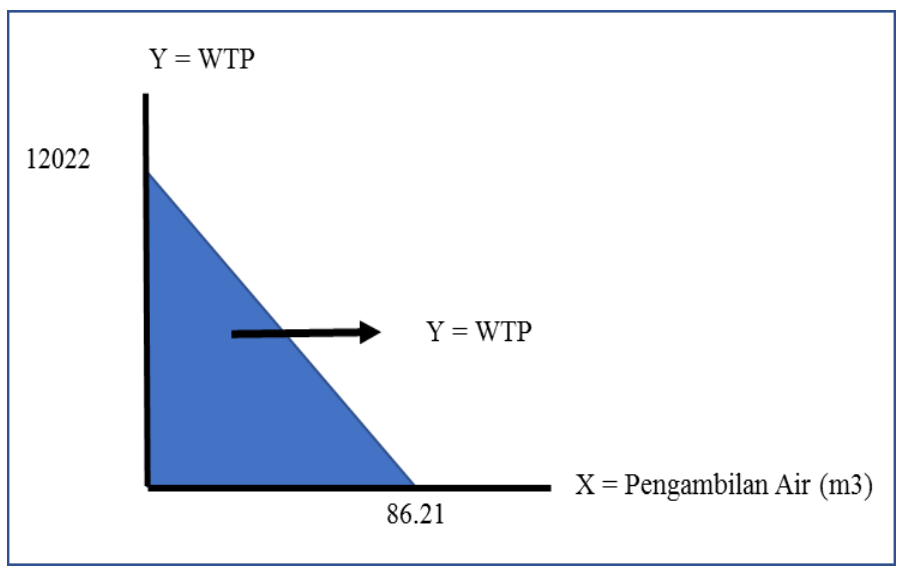

Gambar 3 Grafik WTP 


\section{Menghitung Besarnya Surplus Produsen}

Adapun surplus produsen adalah jumlah yang dibayarkan oleh produsen dikurangi biaya produksi. Surplus produsen menggambarkan manfaat yang diterima produsen ketika produsen terlibat di pasar. Suplai pasar menggambarkan biaya marjinal untuk memproduksi barang dan jasa, sedangkan permintaan pasar menggambarkan marginal benefit dari mengkonsumsi barang dan jasa. Net Social Benefit atau surplus pasar adalah selisih antara manfaat yang diperoleh masyarakat dari memproduksi sumber daya alam dan biaya yang dikeluarkan untuk memproduksinya. Angka ini berhubungan dengan total surplus produsen karena surplus produsen untuk satu produsen individual merupakan manfaat marjinal produsen tersebut atau selisih antara apa yang seharusnya dibayarkan dibandingkan jumlah sebenarnya yang dia bayarkan (Besanko et al., 2000).

Berdasarkan data yang diperoleh besarnya biaya produksi rata-rata Rp 146250/hari dengan jumlah debit air yang diambil rata-rata 42 tangki, sehingga biaya rata-rata per tangki sebesar Rp 3482, sehingga terjadi surplus produsen untuk setiap tangki sebesar: nilai WTP - harga produksi $=\mathrm{Rp} 31000-\mathrm{Rp} 3482=\mathrm{Rp} 30997$. Jika digambarkan dalam grafik seperti terlihat pada Gambar 4 di bawah ini.

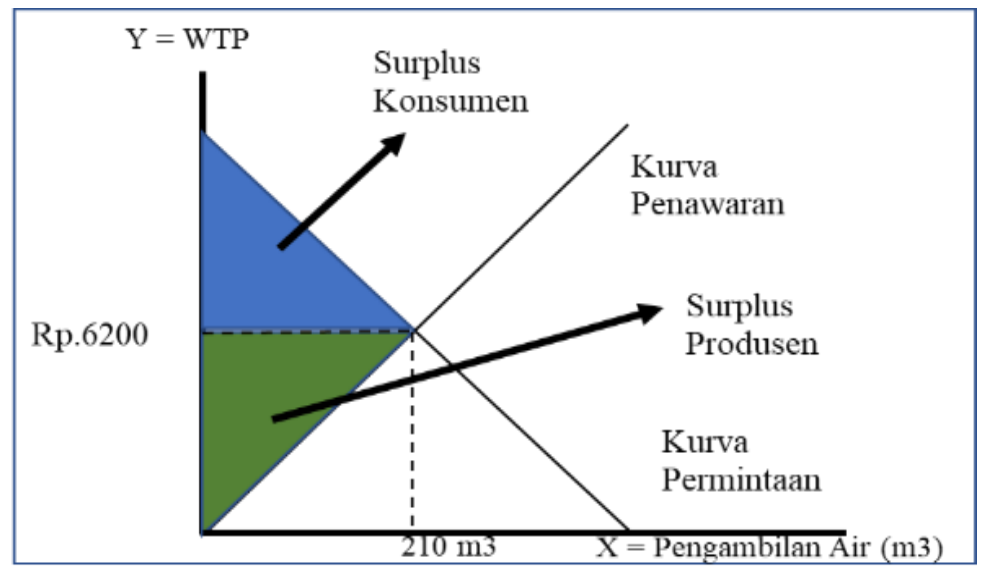

Gambar 4 Grafik surplus produsen

\section{Menghitung Besarnya Surplus Konsumen}

Surplus konsumen selisih antara manfaat yang diperoleh masyarakat dari memproduksi sumberdaya alam dan biaya yang dikeluarkan untuk memproduksinya. Dapat dilihat pada rumus:

Keterangan :

$$
\mathrm{SK}=\sum(\mathrm{WTP}-\mathrm{P}) \text { dimana } \mathrm{WTPi}>\mathrm{P}
$$

SK $=$ Surplus konsumen

WTPi $=$ WTP responden ke-i

$\mathrm{P} \quad=\mathrm{WTP}$ rata-rata

Pada penelitian ini surplus konsumen responden terhadap pembayaran jasa lingkungan sumber daya air tanah sumur yang dikomersilkan adalah selisih antara nilai WTP sebesar Rp 527000 dan WTP rata-rata sebesar Rp 31000 maka nilai surplus konsumen sebesar Rp 496000. Jika digambarkan dalam grafik seperti terlihat pada Gambar 5. 


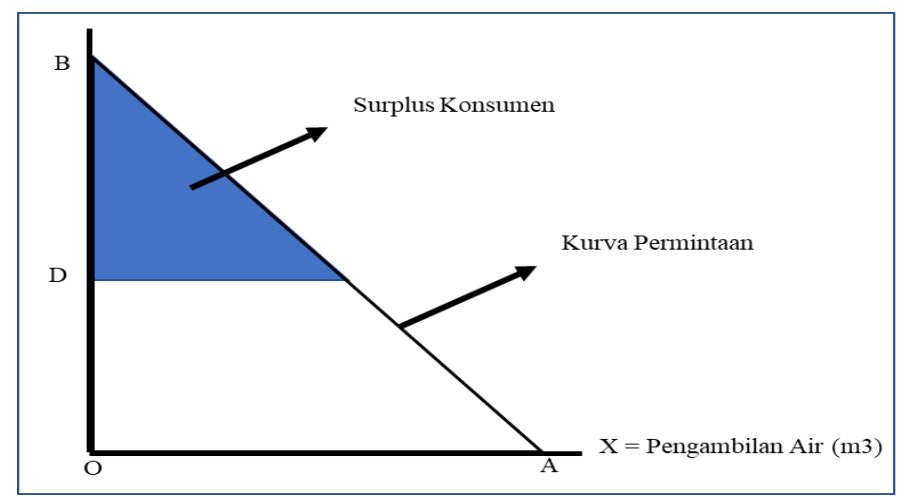

Gambar 5 Grafik surplus konsumen

\section{Analisis Tingkat Risiko Kesediaan Membayar Responden (WTP)}

Tabel 6 menerangkan interpretasi nilai korelasi dan tingkat hubungannya. Adapun Tabel 7 menunjukan tingkat risiko WTP yang diperoleh dengan menghitung nilai koefisien variasi (CV) yaitu hasil bagi antara nilai standar deviasi dengan nilai WTP. Nilai rata-rata (mean) dan standar deviasi dari masing-masing faktor risiko berdasarkan hasil output SPSS. Dari hasil analisis pada Tabel 7 dapat disimpulkan bahwa faktor-faktor risiko yang memiliki tingkat risiko rendah adalah Umur (X1), Pendidikan (X2), Pekerjaan (X3), Biaya (X5), sedangkan faktor risiko yang memiliki tingkat risiko kuat adalah Penerimaan (X4) dan PengJasaLing (X6). Untuk faktor risiko Umur (X1), Pendidikan (X2), Pekerjaan (X3), Biaya (X5) memiliki tingkat risiko rendah, hal ini berarti bahwa faktor tersebut bukanlah faktor risiko yang dapat menimbulkan risiko yang tinggi terhadap kesediaan responden dalam membayar (WTP). Sedangkan Penerimaan (X4) dan PengJasaLing (X6) memiliki faktor risiko kuat artinya bahwa faktor tersebut menimbulkan risiko yang kuat terhadap kesediaan responden dalam membayar (WTP).

Tabel 6 Interpretasi koefisien korelasi (nilai R)

\begin{tabular}{cc}
\hline Interval Koefisien & Tingkat Hubungan \\
\hline $0.80-1.000$ & Sangat Kuat \\
$0.60-0.799$ & Kuat \\
$0.40-0.599$ & Cukup Kuat \\
$0.20-0.399$ & Rendah \\
$0.00-0.199$ & Sangat Rendah \\
\hline
\end{tabular}

Sumber: Ridwan, 2010

Tabel 7 Tingkat risiko WTP

\begin{tabular}{lcccc}
\hline \multicolumn{1}{c}{ Faktor Risiko } & Mean & Std. Deviation & CV & Tingkat Risiko \\
\hline Umur $\left(\mathrm{X}_{1}\right)$ & 52.85 & 12.696 & .066 & Risiko rendah \\
Pendidikan $\left(\mathrm{X}_{2}\right)$ & 2.65 & .988 & .129 & Risiko rendah \\
Pekerjaan $\left(\mathrm{X}_{3}\right)$ & .65 & .489 & -.110 & Risiko rendah \\
Penerimaan $\left(\mathrm{X}_{4}\right)$ & 435.00 & 256.546 & .617 & Risiko kuat \\
Biaya $\left(\mathrm{X}_{5}\right)$ & 146.25 & 82.028 & -.159 & Risiko rendah \\
PengJasaLing $\left(\mathrm{X}_{6}\right)$ & .85 & .366 & .569 & Risiko cukup kuat \\
\hline WTP & \multicolumn{5}{c}{31.000} \\
N & \multicolumn{5}{c}{20} \\
\hline
\end{tabular}

Sumber: Hasil analisis, 2018 


\section{KESIMPULAN}

Nilai WTP pemilik sumur yang bersedia membayar sebanyak 17 responden adalah sebesar Rp 518209 atau Rp 6100 setiap meter kubik. Nilai WTP ini masih relatif rendah karena baik produsen maupun konsumen masih membayar lebih rendah daripada yang seharusnya. Meskipun demikian, upaya meningkatkan harga air perlu memperhatikan faktor-faktor yang mempengaruhi kesediaan konsumen untuk membayar. Dalam hal harga air tanah di Kota Kupang, hasil uji menunjukkan bahwa faktor-faktor risiko yang memiliki tingkat risiko rendah adalah Umur $\left(\mathrm{X}_{1}\right)$, Pendidikan $\left(\mathrm{X}_{2}\right)$, Pekerjaan $\left(\mathrm{X}_{3}\right)$, Biaya $\left(\mathrm{X}_{5}\right)$, sedangkan faktor risiko yang memiliki tingkat risiko kuat adalah Penerimaan $\left(\mathrm{X}_{4}\right)$ dan PengJasaLing $\left(\mathrm{X}_{6}\right)$. Untuk faktor risiko Umur $\left(\mathrm{X}_{1}\right)$, Pendidikan $\left(\mathrm{X}_{2}\right)$, Pekerjaan $\left(\mathrm{X}_{3}\right)$, Biaya $\left(\mathrm{X}_{5}\right)$ memiliki tingkat risiko rendah, hal ini berarti bahwa faktor tersebut bukanlah faktor risiko yang dapat menimbulkan risiko yang tinggi terhadap kesediaan responden dalam membayar (WTP). Sedangkan Penerimaan $\left(\mathrm{X}_{4}\right)$ dan PengJasaLing $\left(\mathrm{X}_{6}\right)$ memiliki faktor risiko kuat artinya bahwa faktor tersebut menimbulkan risiko yang kuat terhadap kesediaan responden dalam membayar (WTP), sehingga pengaruh yang signifikan secara parsial yaitu antara penerimaan dan pengetahuan jasa lingkungan terhadap kesediaan pemilik sumur dalam membayar jasa lingkungan air tanah yang dijadikan economic goods. Penerimaan dan pengetahuan jasa lingkungan mempunyai pengaruh yang signifikan karena semakin besar penerimaan dan tahu tentang jasa lingkungan maka kesediaan membayar jasa lingkungan semakin tinggi.

\section{DAFTAR PUSTAKA}

Besanko D, Darnove D, Shanley M, Schaefer S. 2009. Economics of Strategy. Amerika (US): John Wiley \& Sons.

Dajan A. 1976. Pengantar Metode Statistik Jilid I. cetakan keempat. Jakarta (ID): LP3ES.

Dixon JA, Hufschmidt M. 1993. Economic Valuation Techniques for The Environmental: A Case Study Workbook. terjemahan oleh Sukanto Reksohadiprodjo. Yogyakarta (ID): Gadjah Mada University Press.

Hosmer DW, Jovanovic B, Lemeshow S. 1989. Best subsets logistic regression. Biometrics. 45(4): 1265-1270. doi: $10.2307 / 2531779$.

Pemerintah Indonesia. 2002. Undang-Undang Dasar Negara Republik Indonesia 1945 Amandemen Keempat. Pasal 33 Ayat 3. Sekretariat Negara. Jakarta.

Peraturan Menteri. 2017. Peraturan Menteri Energi dan Sumber Daya Mineral Republik Indonesia No. 2 Tahun 2017 tentang Cekungan Air Tanah di Indonesia. Berita Negara Republik Indonesia Tahun 2017, No. 56. Sekretariat Negara. Jakarta.

Rahaman MM, Varis O. 2005. Integrated water resources management: evolution, prospects and future challenges. Sustainability: $\quad$ Science, $\quad$ Practice and Policy. 1(1): 15-21. doi: 10.1080/15487733.2005.11907961.

Salean J. 2017 Apr 21. Pengeboran air tanah perlu diatur. Antara News [Internet]. Tersedia pada: https://kupang.antaranews.com/berita/2828/pengeboran-air-tanah-perlu-diatur.

Sultana F, Loftus A. 2013. The Right to Water: Politics, Governance and Social Struggles [Internet]. London (GB): Eartscan. hlm 1-18; [diunduh 2018 Mei 14]. Tersedia pada: https://www.researchgate.net/profile/ Farhana_Sultana/publication/290189286_The_Right_to_Water_Prospects_and_Possibilities/links/569 51fd708ae3ad8e33d4d7c/The-Right-to-Water-Prospects-and-Possibilities.pdf.

Walpole RS. 1988. Introduction to Statistics Third Edition: Pengantar Statistika Edisi ke-3. terjemahan oleh Bambang Sumantri. Jakarta (ID): PT. Gramedia Pustaka. 